\title{
The Language of Set Monologues in David Milch's Deadwood
}

\author{
Richard D. Cureton and Jeffrey Quackenbush \\ Professor Emeritus, University of Michigan, 500 S State St, Ann Arbor, MI 48109, United States
}

\section{ARTICLE INFO}

Article history

RECEIVED: 22-Jul-2019

REVISED: $13-$ Sep-2019

ACCEPTED: 07-Oct-2019

Published: 16-Dec-2019

*Corresponding Author

Email: rcureton@umich.edu

In 1874, gold was discovered in the Black Hills of South Dakota. At the time, this territory had been secured by the Fort Laramie Treaty of 1868 for a few different Native American groups, and was not technically controlled or administered by the United States federal government. By 1876 , the territory had been invaded by non-Native fortune seekers, particularly in areas around the justformed town of Deadwood, and a series of engagements fought between the US Army and a coalition of Native groups culminated in the breaking of the Treaty and the formal annexation of the Black Hills to the United States. The TV show Deadwood, which first aired on HBO in March 21, 2004 and ran three seasons, covered events in the town between 1876 and 1877. The series won eight Emmys and received 28 nominations. A postscript to the series, Deadwood: The Movie, aired in May 2019, and followed up on developments in the town in 1889, when South Dakota was admitted as a state to the Union.

The ferment of those years provided a rich set of historical details for the show, but rather than merely dramatize this history, David Milch, the showrunner and main writer of the series, chose to transmute it in the service of examining, expansively, a broad range of the town's residents, its social forms, and the human condition. Milch lead a remarkably varied life prior to Deadwood. He had a tremendously successful career in television, working on Hill Street Blues, creating NYPD Blue, and earning a fortune. Before getting into television, he did stint in Mexico working for a drug cartel and was a professor of literature and creative writing at Yale and good friends and colleagues with the likes of Robert Penn Warren and Cleanth Brooks. His father had been a prominent surgeon in Buffalo, while members of his extended family were involved in organized crime. Over the years, he has struggled with childhood sexual abuse, alcoholism, drug addition, gambling addiction, bipolar disorder, massive IRS debt and a serious heart condition; recently, he was diagnosed with Alzheimer's disease. He has been married to the same woman for 37 years and has three adult children.

Deadwood is famously distinctive in its use of language, and that is our interest here, too. The series simply would not have the same impact if it had not cultivated such an original, literary voice. For example, characters often mix artful, serpentine syntax and purple diction with swearing and INVENTIVE INVECTIVE as they spar, verbally. To reproduce the emotional effect of the blasphemy that would have been common in the town's milieu, Milch used obscenity; from moment to moment, the language of Deadwood might be some of the most obscene language in the history of TV drama. According to blogger Jeff Kay, who counted them up, the word fuck, in one or another of its forms, is used 55 times in first hour of the series, and in the three seasons of the series plus the movie, the word fuck is used a total of 3,063 times, or 1.51 fucks a minute (FPM). Episode 8 of season 2 contains the peak FPM rate of the whole series at 2.69 , or one fuck about every 22 seconds. In the series, the word cocksucker is also a favorite, so much so that a YouTube video documents, in rapid fire, its many contexts of use:

https://www.youtube.com/watch?v=u4D3UdxM30U\& has_verified $=1$

The themes of Deadwood and the social issues it confronts are many - the settling of the West, power, politics, money, property, violence, racism, immigration, prostitution, God, etc. - and these issues are not small at all; they're large, profound. But it is generally agreed that the overarching theme of Deadwood is one of the deepest questions imaginable. How does civilization come together from chaos by organizing itself around symbols? In spite of the obscenity and the localized historical setting, then, to confront the gravity of this lofty theme, Milch elevates his language rhythmically, sonically, prosodically, syntactically, rhetorically, symbolically, etc., 
so much so that, in some cases, for example, the many set monologues, the language is overtly and obviously Shakespearean. Because of Milch's voice, the heightened register of the dialogue succeeds spectacularly, in spite of the rowdy nature of the characters, the topics addressed, and the American western setting.

What is usually meant by "Shakespearean" is that some bit of language is intensely poetic and lyrical in a dramatic context, not that it strictly follows the stylistic arrangements of Shakespeare's actual work. With Temporal Poetics, ${ }^{1}$ we spell out exactly what this denotes: poetry is formal; form comes from rhythm, organizing itself according to the qualities of the components of rhythm, meter, grouping, prolongation, and theme; lyric most intimately conforms with the "centering" ethos of grouping. In reviewing Milch's series, we have used this theory of poetry, described in great detail elsewhere, to look closely at the language of Deadwood, in particular at the language of its set monologues, which often display the Shakespearean language of the series most strikingly. By observing, describing, interpreting, and evaluating this language, we have sought an assessment of how Milch's poetic intent contributes to the aesthetic accomplishment of his dramatic and cinematic creation.

In this article, we will look briefly at one speech, a sermon taken from the middle of episode five in the first season. It is given by the local reverend, Henry Weston Smith, at the funeral of Wild Bill Hickok, who had been shot to death in the previous episode. His sermon draws liberally from the King James version of First Corinthians, Chapter 12 , but it is much more than an interpretive rendition, both in its form and in the sentiments it gives utterance to. Here is the monologue in a block of text:

"Mr. Hickok will lie beside two brothers. One he likely killed; the other he killed for certain. And he's been killed now in turn. So much blood. And on the battlefields of the Brothers' War, I saw more blood than this, and asked then after the purpose. And did not know. And don't know the purpose now. But know now to testify that, not knowing, I believe. St. Paul tells us: by one spirit are we all baptized into one body, whether we be Jew or Gentile, bond or free, and have all been made to drink into one spirit, for the body is not one member, but many. He tells us: the eye cannot say unto the hand I have no need of thee. Nor again, the head to the feet I have no need of thee. They, much more, those member of the body which seem more feeble, and those members of the body which we think of as less honorable, all are necessary. He says that there should be no schism in the body but the members should have the same care one to another, and whether one member suffers, all the members suffer with it. I believe in God's purpose, not knowing it. I ask him, moving in me, to allow me to see his will. I ask him, moving in others, to allow them to see it."

A striking feature of this funeral sermon is its continuous metricality (or "beating"). If we represent syllables that get major/tactical beats with dots, the passage falls into 25 metrical lines fashioned into two metrical sections and having of two and then three stanzas and five two-part stanzas having four to six lines each.

(25 lines, 5 stanzas, 10 parts)

Section 1, Stanza 1, Part 1

Mister Hickok will lie beside two brothers,

tactus

one he likely killed, the other he killed for certain

. . . . . tactus

Section 1, Stanza 1, Part 2

and he's been killed now in turn.

tactus

So much blood.

. . . tactus

Section 1, Stanza 2, Part 1

And on the battlefields of the Brothers' War,

tactus

\footnotetext{
${ }^{1}$ Richard Cureton's Temporal Poetics is a theory of poetry that derives poetic form from the qualities of poetic rhythm. For an overview of Temporal Poetics, see Cureton's 2015 essay on "Inner Form." For Cureton's theory of poetic rhythm, see Rhythmic Phrasing In English Verse, published in 1992, and the long article, "Meter and Metrical Reading in Temporal Poetics," published in 2012. For some sample analyses using temporal poetics, see the other articles by Cureton referenced in the Works Cited. The analysis that follows is based on this theory.
} 
I saw more blood than this,

. . tactus

Section 1, Stanza 2, Part 2

and asked then after the purpose. And did not know.

. . . tactus

And don't know the purpose now.

$$
\text { . . tactus }
$$

But know now to testify that, not knowing, I believe.

tactus

Section 2, Stanza 1, Part 1

St. Paul tells us: by one spirit

. tactus

are we all baptized into one body,

tactus

Section 2, Stanza 1, Part 2

Whether we be Jew or Gentile, bond or free,

.

And have all been made to drink into one spirit,

For the body is not one member, but many. He tells us:

tactus

Section 2, Stanza 2, Part 1

the eye cannot say unto the hand I have no need of thee. Nor again

tactus

the head to the feet I have no need of thee. They, much more,

tactus

Section 2, Stanza 2, Part 2

those members of the body which seem more feeble,

. tactis

and those members of the body which we think of as less honorable,

all are necessary. He says that

. . . . . tactus

Section 2, Stanza 3, Part 1

there should be no schism in the body

. . . . tactus

but the members should have the same care one to another,

tactus

and whether one member suffers, all the members suffer with it.

. . . . . . . tactus

Section 2, Stanza 3, Part 2

I believe in God's purpose, not knowing it.

. tactus

I ask him, moving in me, to allow me to see his will.

tactus

I ask him, moving in others, to allow them to see it.

tactus 
And so, arranged on the page as a poem, we get this:

Mr. Hickok will lie beside two brothers, One he likely killed, the other he killed for certain And he's been killed now in turn. So much blood.

And on the battlefields of the Brothers' War, I saw more blood than this,

And asked then after the purpose. And did not know. And don't know the purpose now.

But know now to testify that, not knowing, I believe.

St. Paul tells us: by one spirit

Are we all baptized into one body,

Whether we be Jew or Gentile, bond or free,

And have all been made to drink into one spirit, For the body is not one member, but many. He tells us:

The eye cannot say unto the hand I have no need of thee. Nor again,

The head to the feet I have no need of thee. They, much more, Those members of the body which seem more feeble,

And those members of the body which we think of as less honorable,

All are necessary. He says that

There should be no schism in the body

But the members should have the same care one to another

And whether one member suffers, all the members suffer with it.

I believe in God's purpose, not knowing it.

I ask him, moving in me, to allow me to see his will.

I ask him, moving in others, to allow them to see it.

Amazingly, and to Milch's credit, the language of this set monologue is not only continuously metrical, but appropriately so in its choice of meter. The speech is a funera sermon, and so the occasion is linear (i.e., about death, an ending). But the sentiment is strongly epic (i.e., about the necessary wholeness of viable human societies/communities) and lyric (a lament for the loss of one piece of that whole). The meter of the piece gives these themes a metaphysical depth by tying their expression to a shapely physicality, with an appropriate rhythm, which itself gives rise to such proportion.

In terms of tactical beating, the lines in the five two-part stanzas in the poem have the following arrangement, with each number representing a line and its count of tactical beats:

\section{SECTION 1}

STANZA $1-5644$

STANZA 2 - 44546
SECTION 2

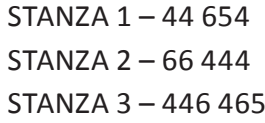

Being square, four-beat lines and four-line stanzas are cyclical/epic; being asymmetrical, five-beat lines and fivebeat stanzas are cenroidal/lyric; and being extended, sixbeat lines and six-line stanzas are linear/narrative. Over half of the lines (14) in this sermon are four-beat and so foreground the central theme of Deadwood as a whole: the need to establish social unity, community, etc. On the other hand, appropriately, each stanza has lines of each of the three sorts, which underpins the countervailing forces that undermine this unity and so accentuate the difficulty, if not impossibility, of this task. And so, appropriately as well, the sermon begins with a 4-line/ epic stanza but ends with a six-line/linear one, with three lyric/5-line stanzas in between. Within stanzas as well, two-line parts of stanzas and never precede three-line parts, and within the sermon as a whole, it is the first section that has two stanzas and the second section that has three. So the general development of the meter both within stanzas, sections, and the sermon as a whole is from cyclical to linear by way of centroidal, epic to narrative by ways of the lyric, the physical to the social by way of the emotional, a pleasing stepwise movement through the first three of the four temporalities in their order of emergence.

Of course, this being a drama, poetic or not, Milch also chooses to resist this vision within his fictional world, in a way that both complicates and complements what the reverend's speech would seem to express. For instance, several scenes after the funeral, Jack McCall, who had shot and murdered Hickok from behind and was immediately trussed up, to be tried by a jury, is freed and escapes the town on a horse. Seth Bullock, a main protagonist who had befriended Hickok prior to his death, is angered by this discharge as he walks back to town, and considers if he should ride after McCall to bring him to justice. He speaks with his business partner and friend, Sol Star, and explicitly rejects an appreciative reading of the sermon:

Bullock: The man is a lunatic. High water he never made much sense, but now? He just utters pure gibberish.

Star: Did he look pale to you?

Bullock: What?

Star: Did he seem pale?

Bullock: How the fuck do I know if he was pale or not? 
Star: He looked pale to me.

Bullock: What if he was? Let's say he was. Will you shut up about it? What is my part, and your part? [in a mocking tone] "What part of my part is your part? Is my foot your knee? What about your ear?" What the fuck is that?

Other speeches and exchanges throughout the show draw upon different resources in meter (and language more generally): some are dipodic; some have a triple pulse; some are completely in tetrameter or pentameter; etc. These alternate patterns have a similar effect as Bullock's reaction, and symbolize the mixture of sensibilities competing within the story and within the nascent society.

In Deadwood, the inclusive social vision articulated in Hickok's funeral speech encompasses even those elements - the idealist, the fortune seeker, the crime boss, the scallywag, the drunk, the gambler, the drifter, the whore - who appear opposed to it, in pursuit of their individual passions or tastes. This striving for wholeness is the civilizing impulse that binds individuals into some emerging sense of a common humanity, in the face of chaos or death. Milch was committed to articulating this vision with, first, the shape of his words, and then, through richly drawn characters, the political machinations of the plotting, the earthy cinematography, and the production's verisimilitude of a 19th century mining town. We would do well to be instructed by his example, here, in 2020 .

\section{References}

Cureton, Richard D. Rhythmic Phrasing in English Verse. London: Longman, 1992.
"Cummings and Temporality." Spring: The Journal of the E. E. Cummings Society New Series No. 16 (Fall 2007): 20-39. Print.

- "Meter and Metrical Reading in Temporal Poetics." Thinking Verse 2 (2012): 112-237. Web.

. "Rhythm, Temporality, and 'Inner Form'," Style 49.1 (2015), 78-109. Print.

_. "A Reading in Temporal Poetics: Emily Dickinson's '। taste a liquor never brewed."' Style 49.3 (2015): 354362. Print

"A Reading in Temporal Poetics: Elizabeth Bishop's 'The Map.'” Style 50.1 (2016): 37-64. Print.

—. "Readings in Temporal Poetics: Four Poems by William Carlos Williams." Style 51.2 (2017): 187-206. Print.

."A Reading in Temporal Poetics: Wallace Stevens' 'Domination of Black'." Style 51.4 (2017): 526-549. Print.

"Deadwood's Favorite Word." YouTube, uploaded by GeLaTaTtAcK, 9 September 2011, https://www.youtube.com/ watch?v=u4D3UdxM30U\&has_verified $=1$.

Kay, Jeff. "The Number Of Fucks In Deadwood." The West Virginia Surf Report! http://thewvsr.com/deadwood/. Accessed 10 September 2019.

Singer, Mark. "The Misfit." The New Yorker, 6 February 2005, https://www.newyorker.com/magazine/2005/02/14/ the-misfit-2. Accessed 10 September 2019.

“David Milch's Third Act." The New Yorker, 20 May 2019, https://www.newyorker.com/magazine/2019/05/27/davidmilchs-third-act. Accessed 10 September 2019.

"Television's Great Writer, David Milch (MIT Communications Forum) 2006." YouTube, uploaded by Kempton Lam, 17 February 2016, https://www.google.com/ url?q=https://www.youtube.com/watch?v\%3DMDTVIP 8bvE\&\&source $=$ gmail \&ust $=1568338919914000 \& u s g=$ AFQjCNFwXYTtJJXTmBssXfyldldMQHfWNg. 
